\title{
Effects of Skidding Operations after Tree Harvesting and Soil Scarification by Felled Trees on Initial Seedling Emergence of Spanish Black Pine (Pinus nigra Arn. ssp. salzmannii)
}

\author{
Manuel Esteban Lucas-Borja ${ }^{1, * \mathbb{D}}$, Mehdi Heydari ${ }^{2}$, Isabel Miralles ${ }^{3}$, \\ Demetrio Antonio Zema ${ }^{4}$ (i) and Ruben Manso ${ }^{5}$ \\ 1 Higher Technical School of Agricultural and Forestry Engineering, Castilla-La Mancha University, \\ Campus Universitario s/n, 02071 Albacete, Spain \\ 2 Forest Sciences Department, Faculty of Agriculture, Ilam University, Ilan 6939177111, Ilam Province, Iran; \\ m.heidari@ilam.ac.ir \\ 3 Department of Agronomy \& Centre for Intensive Mediterranean Agrosystems and Agri-Food \\ Biotechnology (CIAIMBITAL), University of Almeria, E-04120 Almeria, Spain; imiralles@ual.es \\ 4 Department AGRARIA, Mediterranean University of Reggio Calabria, Località Feo di Vito, \\ I-89122 Reggio Calabria, Italy; dzema@unirc.it \\ 5 Forest Research, Northern Research Station, Bush Estate, Roslin EH25 9SY, UK; \\ ruben.manso@forestresearch.gov.uk \\ * Correspondence: ManuelEsteban.Lucas@uclm.es
}

Received: 24 June 2020; Accepted: 15 July 2020; Published: 17 July 2020

check for updates

\begin{abstract}
Skidding operations are thought to have negative impacts on soil emergence because they may increase soil compaction and reduce vegetation cover and the soil's organic matter content. We investigated whether and to what extent tree harvesting and subsequent skidding initially altered seedling emergence in two Mediterranean forests of Pinus nigra Arn. ssp. salzmannii (Spanish black pine) in the Cuenca Mountains (Spain). Our main objective was to compare the Spanish black pine seedling emergence rate among skid trails, soil areas scarified by felled trees, and areas undisturbed next to harvest operations. In addition, we selected an unmanaged stand as reference, in order to look for evidence of seedling emergence under natural conditions. We measured Spanish black pine seed fall and seedling emergence immediately after harvest operations in two locations in the Cuenca Mountains (Palancares and Majadas forests), which are typical forests in Cuenca Mountains. The results showed that the Palancares site presented higher seed fall in comparison to the Majadas site. In addition, seed fall was higher in the unmanaged stand, as we recorded a higher tree density in this site in comparison to harvested stands (Palancares and Majadas). Furthermore, our results demonstrated differences in seedling emergence between lower elevation drier Palancares and higher elevation wetter Majadas and relative differences in seedling emergence among skid trail, scarified, and undisturbed harvested areas. Finally, the unmanaged stand presented the highest seedling emergence in comparison to scarified, compacted, and non-disturbed harvested areas. Overall, the results suggest a short-term impact of skidding on seedling emergence, which should be considered for future management guidelines of Spanish black pine in the Mediterranean climate.
\end{abstract}

Keywords: seedling emergence; seedling survival; forest management; skid trails; Mediterranean forest 


\section{Introduction}

Tree harvesting is used primarily to obtain commercial timber values and improve stand structure, health, and growth, but may also be prescribed to regenerate forest stands, reduce possible insect and disease outbreaks as well as limit fire recurrence and safety hazards [1-3]. The pros (e.g., economic benefits, reduced fire susceptibility, increased worker safety and access) and cons (e.g., increased soil compaction, increased hydrologic responses, and short-term loss of habitat) of tree harvesting have been debated for years. The debate continues, particularly in the Mediterranean Basin and in other areas with Mediterranean climates, where rainy autumns, winters, and springs contrast with prolonged summer droughts [4]. Tree harvesting generates a disturbance, which alters vegetation structure [5-7] and the physical properties of soils [8,9], particularly aggregate stability, bulk density, and hydraulic conductivity. Following tree harvesting or logging, pine species regenerate through interactions among materials that function in propagating trees to the next stage in their life cycle, including seeds in seed banks and those dispersed into a site [10]. The distribution and persistence of current pinewoods in the Mediterranean landscapes relies on their capacity to successfully regenerate [11]. However, natural regeneration processes in these areas are slow and unpredictable because they are influenced by complex interactions among multiple factors operating on different spatiotemporal scales. Among these factors, canopy plant species characteristics, understory vegetation interactions, soil properties, pre- and post-dispersal seed predation, and microclimatic conditions are the most important [12-14]. Although the success of natural forest regeneration depends on events occurring during the entire tree lifespan, early life stages such as seedling emergence or seedling survival are particularly critical due to their vulnerability to biotic and environmental constraints $[15,16]$. Drought and soil desiccation, for example, are primary constraints to seedling establishment in many forest areas characterized by long and dry summer periods [17]. In such areas, recruitment processes are often restricted to sporadic rainfall periods or wet microsites resulting in pulses of recruitment rather than a continuous and regular seedling establishment [18].

Machinery used during tree harvesting or logging generates important changes in the forest floor and soil environments, which may directly affect natural forest regeneration. As the author of [19] observed, skid trails are used in ground-based logging operations to transport trees, logs, and other forest products to a deck, landing, or roadside. Harvest activities may generate soil compaction, which might limit the effective rooting depth of plants and subsequent uptake of water or nutrients, as well as reduced gas exchange [20]. As was demonstrated in [21], the compact soil resulting from tree harvesting produces a reduction in size and continuity of soil macropores through which roots preferentially grow, leading to slower root elongation, reduced root length, and reduction in exploited soil volume. On the contrary, soil scarification generated by felled trees during harvesting may have a positive effect on initial seedling recruitment. In [22], the authors showed in greater detail that soil preparation results in higher seed germination percentages in Spanish black pine forest stands. Other authors have reported that soil preparation directly alters seed-growing conditions, which can result in the suppression of water and nutrient competitors for seedlings, an increase in soil moisture and temperature, and a reduction in soil density [22,23]. Overall, little is known about the impact of tree harvest operations (including skidding and any associated soil compaction or soil scarification where felled trees are placed) on initial seedling recruitment [24]. This information would help forest managers to better plan harvest operations, particularly in Spanish black pine Mediterranean forests.

Germination, represented as the first visual appearance of the radicle from the outermost structure enveloping the embryo, is an important phenological event that influences the success of the initial seedling recruitment. Recently, the most important problems in the regeneration of Spanish black pine have been identified as follows: the state of the soil surface (compacted or pastures), the highly variable annual production of seeds (masting), grazing, and attacks by European pine shoot moths on seedlings [22,25]. Moreover, during many seasons, the establishment and development of regeneration depends on microclimatic conditions, particularly the temperature at both air and the soil surface, and also on soil moisture, as this directly affects growth and indirectly affects biological and chemical 
processes [25]. The relative importance of these factors will depend on the season and superficial soil treatment [26].

Seed germination represents a risky transition from the stage most tolerant of various environmental conditions (i.e., resting seed) to the weakest and most vulnerable stage in plant development, the seedling [27]. The soil characteristics and pine seedling emergence partially depend on the implementation of tree harvest operations. Thus, we conducted this study in two Spanish black pine forest areas to investigate the effects of skidding operations and soil scarification on seedling emergence. Therefore, the objective of this research was to compare the Spanish black pine seedling emergence rate immediately after harvest in areas in the skid trails, soil areas created by felled trees, and undisturbed areas. In addition, an unmanaged stand was selected as a reference and to quantify seedling emergence under natural conditions. We hypothesized that soil compaction after skidding operations may have a detrimental effect on Spanish black pine seedling emergence, whereas soil scarification by logged trees may generate better conditions for seedling emergence in comparison to non-harvested forest stands.

\section{Materials and Methods}

\subsection{Study Area}

The study area is in the Cuenca Mountains (in eastern-central Spain, Figure 1). Spanish black pine (Pinus nigra Arn. ssp. salzmannii) is naturally distributed in this area, between 1000 and $1500 \mathrm{~m}$ above sea level, and dominates the forest stand composition [25]. A dense Spanish black pine forest was selected at $1200 \mathrm{~m}$ above sea level (Palancares site; $40^{\circ} 01^{\prime} 50^{\prime \prime} \mathrm{N}, 1^{\circ} 59^{\prime} 10^{\prime \prime} \mathrm{W}$ ), representing the core of the Spanish black pine range in the study area. A second experimental site was selected at $1490 \mathrm{~m}$ above sea level (Majadas site; $40^{\circ} 14^{\prime} 30^{\prime \prime} \mathrm{N}, 1^{\circ} 58^{\prime} 10^{\prime \prime} \mathrm{W}$ ), representing the upper elevation limit of Spanish black pine in the range. Here, Scots pine (Pinus sylvestris) sometimes dominates the forest stand composition, displacing Spanish black pine to isolated or relict populations that are further fragmented into smaller stands.

The two experimental sites are about $50 \mathrm{~km}$ apart. Mean annual temperature, mean highest temperatures of the hottest month, and mean lowest temperatures of the coldest month were $9.6^{\circ} \mathrm{C}$, $28.3^{\circ} \mathrm{C}$, and $-4.5^{\circ} \mathrm{C}$ at the Majadas site, and $11.9^{\circ} \mathrm{C}, 30.5^{\circ} \mathrm{C}$, and $-0.5^{\circ} \mathrm{C}$ at the Palancares site, respectively. A mean annual rainfall of $1137 \mathrm{~mm}$ (139 mm during summer) is recorded for Majadas, while $595 \mathrm{~mm}$ ( $99 \mathrm{~mm}$ during summer) is documented for Palancares. For both experimental sites, a drought period of about three months usually occurs. Soils can be classified as Typical Xerorthent in Majadas, and as Lithic Haploxeroll in Palancares, according to Soil Survey Staff (1999) [28]. Herbaceous vegetation is mainly characterized by Eryngium campestre L., Thymus bracteatus L., and Geranium selvaticum L. in Majadas, and by Eryngium campestre L., Geranium selvaticum L., Centaurea paniculata L., and Plantago media L. in Palancares. These types of forest ecosystems are included in the European Union endangered habitats, a listing of natural habitats requiring specific conservation measures (Resolution 4/1996 by the Convention on the Conservation of European Wildlife and Natural Habitats) and in the Protected Areas listing of the Government of Castilla La Mancha (2/2001, Official Diary of Castilla La Mancha $\mathrm{N}^{\circ}$ 8). Since the end of the nineteenth century, Spanish black pine forest stands have been managed under different systems in the Cuenca Mountains. Keeping the forest under age-class management, using a shelterwood system with a 100- to 120-year rotation and a 20- to 30-year regeneration period, is one of the most prescribed methods in Spanish black pine forest management plans [15]. This method generates compartments with a defined forest structure and forest age at the end of the rotation period. 


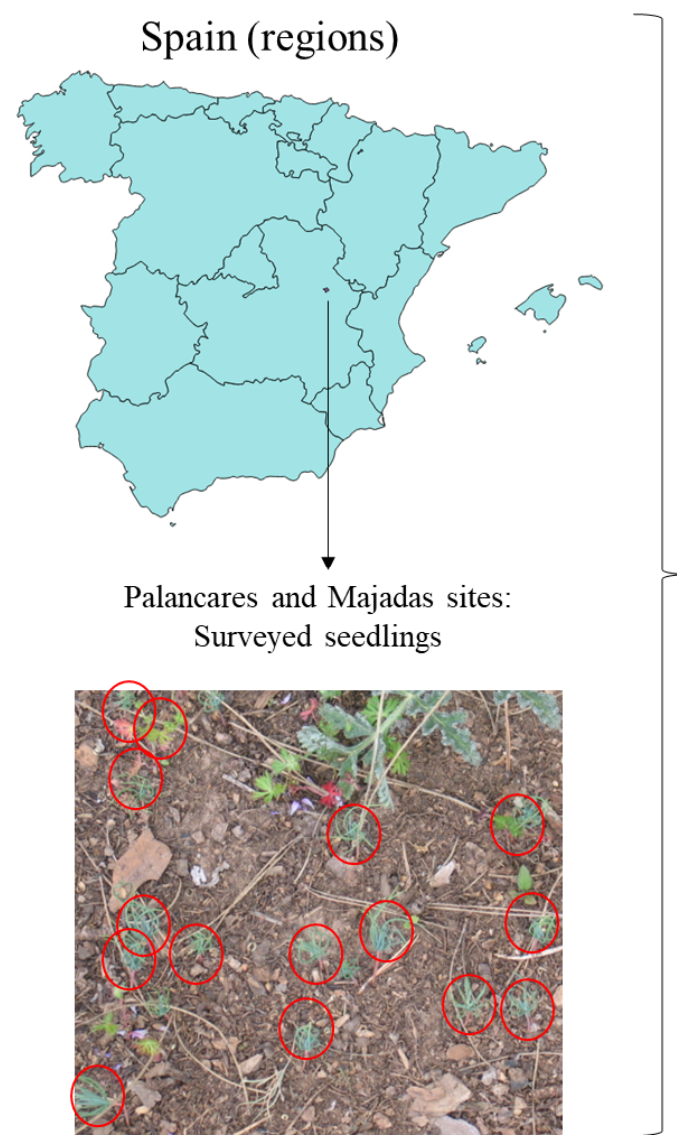

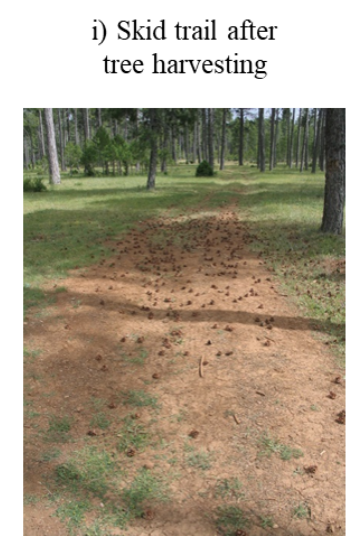

iii) Undisturbed soil

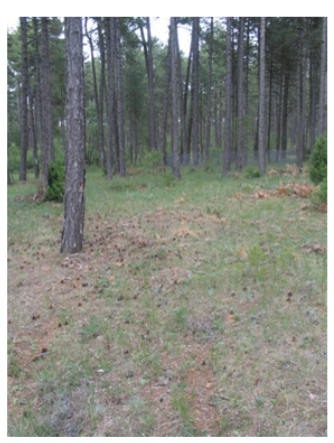

ii) Scarified soil

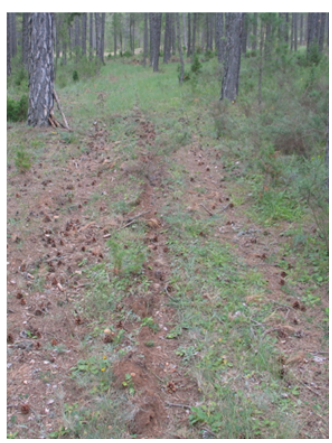

iv) Unmanaged

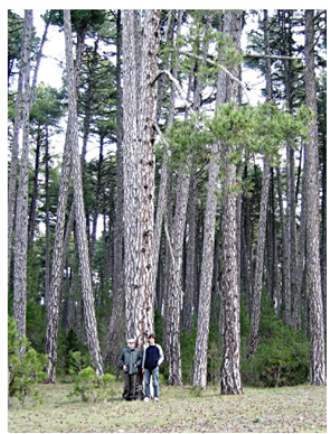

Figure 1. Study site and experimental conditions of Spanish black pine forests subjected to treatments in Cuenca Mountains (Spain).

\subsection{Experimental Design}

In October 2013, previous to harvest operations (seed cut of a shelterwood system) in December 2013 and Spanish black pine seed fall in late January 2014, we selected nine plots at each forest area (both the Palancares and Majadas sites), as follows: (i) three plots on skid trails (hereinafter indicated as "compaction" treatment); (ii) three plots on soil areas scarified by felled trees ("scarification" treatment); and (iii) three plots in areas undisturbed by harvest operations ("undisturbed"). Plot sizes were $10 \mathrm{~m}$ in width $\times 50 \mathrm{~m}$ in length, covering the tracks of skid trails, the soil areas scarified by felled trees, and undisturbed forests, respectively. The distance between plots was always more than $100 \mathrm{~m}$.

A third unmanaged forest area of about 4 ha (Sumidero)—not subjected to tree harvest and henceforth indicated as "natural" - was also identified in the Palancares forest site, to compare seedling emergence under natural conditions. This area was left as unmanaged for ecological protection in 1945 by forest local authorities and has the same stand and soil characteristics as the Palancares forest, except for the features reported in Table 1.

A three-person felling crew, i.e., chainsaw operator, helper, and guide, carried out the felling. The chainsaw (Stihl 070, Waiblingen, Alemania) was equipped with a $75 \mathrm{~cm}$ bar. After felling, the helper completed topping of the crown. A Caterpillar 528 rubber-tire skidder carried out skidding. The felled trees were pulled to the skid trail by a skidder using a $30 \mathrm{~m}$ long cable. This produced a concentration of logs at the skid trail. This procedure allowed us to identify scarified areas as different from the skid trails. These were the sites designated as the scarified plots. Although not measured in this study, soil compaction in areas subjected to skid trails due to the traffic of logging trucks is expected.

During the second phase, the wheel skidder was used for long distance movement of logs to the landing site. A guide had previously done skid trail planning during operations, locating felled trees and marking a way for the skidder. Skid trails generated after the second phase were designated as 
skid trail treatment. The skidder was equipped with front blades and single cable drums. Skid trails avoided water and swampy areas.

One month after the Spanish black pine seed fall ended in late June 2014, a total of fifteen sampling subplots of $0.25 \mathrm{~m}^{2}$ were randomly set up at each plot (two experimental areas $\times$ three treatments $\times$ three plots per treatment $\times 15$ subplots per plot $=270$ sampling units). In the Sumidero unmanaged forest, 45 subplots, each one of $1 \mathrm{~m}^{2}$, were set up, and 45 additional sampling units were identified. Therefore, the total number of sampling units in this study was 315 .

Table 1. Mean and standard error for selected stand and soil characteristics (measured at a depth of $30 \mathrm{~cm}$ ) at three experimental Spanish black pine stands (Cuenca Mountains, Spain) after tree harvesting in late December 2013.

\begin{tabular}{cccc}
\hline \multirow{2}{*}{ Stand and Soil Attribute } & \multicolumn{3}{c}{ Experimental Area } \\
\cline { 2 - 4 } & Palancares-Harvested & Majadas-Harvested & Sumidero-Unmanaged \\
\hline Density (trees ha ${ }^{-1}$ ) & $640 \pm 41$ & $656 \pm 50$ & $1199 \pm 129$ \\
Basal area $\left(\mathrm{m}^{2} \mathrm{ha}^{-1}\right)$ & $25 \pm 5$ & $25 \pm 6$ & $49 \pm 6$ \\
Total tree height (m) & $13 \pm 6$ & $11 \pm 3$ & $33 \pm 4$ \\
Shrub cover (\%) & $53 \pm 5$ & $51 \pm 7$ & $41 \pm 7$ \\
pH & $6.37 \pm 0.52$ & $6.83 \pm 0.52$ & $9.86 \pm 0.31$ \\
Organic matter (\%) $_{\mathrm{NO}_{3}{ }^{-}\left(\mathrm{mg} \mathrm{kg}^{-1}\right)}^{7.48 \pm 0.40}$ & $7.18 \pm 0.40$ & $4.11 \pm 0.33$ \\
Water-holding capacity (\%) & $27.72 \pm 1.27$ & $28.12 \pm 1.27$ & $32.29 \pm 1.39$ \\
C/N & $6.68 \pm 0.16$ & $6.14 \pm 0.16$ & $8.37 \pm 0.38$ \\
& $10.44 \pm 0.19$ & $10.14 \pm 0.19$ & $8.58 \pm 0.46$ \\
\hline
\end{tabular}

\subsection{Characterization of the Forests and Soils}

The different characteristics of plants and soils of the forest stands were measured (mean \pm standard error at each experimental site (Table 1) $[15,29]$. Plant characteristics were measured using three linear transects $(1 \mathrm{~m}$ width $\times 10 \mathrm{~m}$ length) randomly distributed at each plot. Soil characteristics were evaluated obtaining three soil samples ( $250 \mathrm{~g}$ each) at each plot. All soil samples were kept in a refrigerated bag and analyzed $5 \mathrm{~h}$ after sampling. Density (trees ha ${ }^{-1}$ ) was obtained by counting all trees inside each plot. Altitude above sea level $(\mathrm{m})$ was obtained by a GPS (model GARMIN GPS 73, GARMIN, Lenexa, KS, USA). Basal area $\left(\mathrm{m}^{2} \mathrm{ha}^{-1}\right)$ was obtained by first measuring the diameter of all trees in the selected plots. Then, we calculated the basal area of each tree in the plot and, finally, we calculated the total basal area. Total tree height $(\mathrm{m})$ was measured using a Suunto Clinometer (model PM-5/360 PC, Madrid, Spain). Shrub cover (\%) was calculated dividing the surface transect covered by shrubs by the total surface transect and multiplied by 100 . Soil variables $(\mathrm{pH}$, organic matter $(\%)$, and $\mathrm{C} / \mathrm{N})$ were calculated following the procedure found in Lucas-Borja [4]. $\mathrm{NO}_{3}{ }^{-}\left(\mathrm{mg} \mathrm{kg}^{-1}\right)$ was extracted from the soil with water and measured colorimetrically after reaction with phenoldisulphonic acid. Finally, water-holding capacity (\%) was calculated as a percentage of the total dry soil weight and as a percentage of volume of soil-in-place.

\subsection{Seed Dispersal and Seedling Emergence Sampling}

Spanish black pine seed fall was estimated using 90 rectangular seed traps $(40 \mathrm{~cm}$ in length $\times 50$ $\mathrm{cm}$ in width $\times 15 \mathrm{~cm}$ in depth), equally distributed across 1 ha in each of the three experimental sites (Palancares, Majadas, and Sumidero) from early January 2014 to the end of May 2014. This means that 30 seed traps were placed in the compaction treatment, another 30 seed traps were placed in the scarification treatment. and, finally, 30 seed traps were placed in the undisturbed sites in the Palancares and Majadas sites. Spanish black pine seed fall was observed during this period in the Cuenca Mountains [25]. The tops of the traps were protected with wire netting to avoid seed predation. Dispersed seeds were collected in late May 2014 using tweezers.

Seedling emergence was represented by the first visual appearance of the radicle from the outermost structure enveloping the embryo. All seedlings from each subplot were visually counted at the end of June 2014. In other words, a seedling survey was developed one month after the end of the 
seed fall period for Spanish black pine on both the Palancares and Majadas sites [15,29]. According to our data, Spanish black pine needs four weeks to emerge after seed fall.

\subsection{Statistical Analysis}

Seed fall was calculated at each experimental treatment (compaction, scarification, undisturbed, and Sumidero) as a sum of seeds found at each seed trap and then referred to $1 \mathrm{~m}^{2}$. Statistical differences among treatments were evaluated by one-way ANOVA (seed fall as an independent variable and forest treatment and location as a factor). With respect to seedling emergence, the response variable was the number of recruits. This kind of response, hereinafter "counts", is usually and successfully modeled under the assumption that it follows a Poisson distribution [30]. However, a preliminary check of the data showed that there were many more zero counts than would be expected at random from a Poisson distribution. This is known as "zero inflation" and it is a common issue in regeneration data $[30,31]$. Ignoring this excess of zeros would lead to biased parameter estimates and standard errors. One way to deal with this issue is to use "zero-inflated models" [32] and we used this approach in this study. Zero-inflated models consider that the data are the result of two separate processes, namely a "binomial process" (occurrence: either recruits are observed or they are not) and a "count process" conditional to occurrence (abundance: if recruits are observed, the number of them observed). We used the Poisson assumption for the abundance process. Further details on zero-inflated models can be found in [30].

Our aim was to study the effect of the different treatments (Compaction, $C$; Scarification, $S$; Undisturbed, $U$; Natural, $N$ ) in the different forests (Majadas, $M$; Palancares, $P$; Sumidero, $S$ ) on recruitment. Given the number of sample units for each treatment in each forest, it was not possible to test both effects simultaneously. We then decided to fit independent models for each factor. The parameterization for the treatments is as follows:

$$
\begin{gathered}
\log \frac{\pi_{T}}{1-\pi_{T}}=\beta_{0, T}+\beta_{1, T} U+\beta_{2, T} S+\beta_{3, T} N \\
\log \lambda_{T}=\gamma_{0, T}+\gamma_{1, T} U+\gamma_{2, T} S+\gamma_{3, T} N
\end{gathered}
$$

where Equation (1) deals with the binomial part and Equation (2) refers to the count part. The terms in Equation (1) are defined as follows: $\pi_{T}$ is the probability of observing a zero count in a sample unit in a given treatment; $N, S$, and $U$ are dummy variables that adopt the value 1 if the observation is for Natural, Scarification, or Undisturbed treatment, respectively; and $\beta_{\mathrm{T}}$ is a vector of estimable parameters. Note that $\beta_{0, T}$ is taken as the reference and therefore represents the effect of the treatment C when $N=S=U=0$.

$\lambda_{T}$ is the number of observed recruits in a sample unit in a treatment, given that there were seedlings at all; and $\gamma_{T}$ is a vector of estimable parameters, where $\gamma_{0, T}$ represents the effect of treatment C. The parameterization for the effect of the forests is as follows:

$$
\begin{gathered}
\log \frac{\pi_{F}}{1-\pi_{F}}=\beta_{0, F}+\beta_{1, F} P+\beta_{2, F} S \\
\log \lambda_{F}=\gamma_{0, F}+\gamma_{1, F} P+\gamma_{2, F} S
\end{gathered}
$$

Again, Equation (3) is the model for the binomial part, whereas Equation (4) deals with the count part. $\pi_{F}$ is the probability of observing a zero count in a sample unit in a given forest; $P$ and $S$ are dummy variables that adopt the value 1 if the observation is for Palancares forest or Sumidero forest, respectively; and $\beta_{\mathrm{F}}$ is a vector of estimable parameters. $\beta_{0, F}$ is taken as the reference and therefore represents the effect of the forest $\mathrm{M}$.

$\lambda_{F}$ is the number of observed recruits in a sample unit in a forest, given that there were seedlings at all; and $\gamma_{F}$ is a vector of estimable parameters, where $\gamma_{0, F}$ represents the effect of forest $F$. 


\section{Results}

With respect to seed fall, it is worthy to note that Palancares treatments presented higher seed fall in comparison to the Majadas treatments. Seed fall (mean and standard error) was $123 \pm 26$ seeds per $\mathrm{m}^{2}$ for the compaction treatment, $113 \pm 21$ seeds per $\mathrm{m}^{2}$ for the scarification treatment, and $117 \pm 33$ seeds per $\mathrm{m}^{2}$ for the undisturbed treatment in the Palancares forest. Moreover, $62 \pm 26$ seeds per $\mathrm{m}^{2}$ were calculated for the compaction treatment, $55 \pm 11$ seeds per $\mathrm{m}^{2}$ for the scarification treatment, and $47 \pm 13$ seeds per $\mathrm{m}^{2}$ for the undisturbed treatment in the Majadas forest. The unmanaged area (Sumidero) showed $212 \pm 18$ seeds per $\mathrm{m}^{2}$. The one-way ANOVA analyses showed that the unmanaged forest showed higher seed fall $(F$-ratio $=77.2, p$-value $<0.05)$ than compaction, scarification, and undisturbed in both Palancares and Majadas.

A summary of descriptive statistics of the number of recruits by treatment and forest is presented in Table 2. Concerning the impact of the different treatments on the probability of observing any recruitment in a given sample unit, both the Natural and the Undisturbed treatments seem to be those that promote occurrence the most. The Scarification treatment is less favorable than Natural and Undisturbed, but had more emergence or occurrence than Compacted. The results in terms of recruit abundance follow a similar pattern as compared to those of occurrence. Given that there is recruitment at all, the number of recruits would be higher in the treatments Natural and Undisturbed than in Scarification and Compacted, which are, in this case, not significantly different from each other. Between Natural and Undisturbed, the latter seems more beneficial for recruitment. The parameter estimates for this model are shown in Tables 3 and 4.

Table 2. Mean and standard error of the number of recruits (response) for the studied treatments (factors) in Spanish black pine forests (Cuenca Mountains, Spain).

\begin{tabular}{cccc}
\hline Treatment & Site & $\begin{array}{c}\text { Mean } \\
\text { (Seedlings } \mathbf{~ m}^{2} \text { ) }\end{array}$ & Std. Error \\
\hline Compaction & Majadas & 0.2 & 0.5 \\
Compaction & Palancares & 1.7 & 2.3 \\
Scarification & Majadas & 2.2 & 1.9 \\
Scarification & Palancares & 3.4 & 2.3 \\
Undisturbed & Majadas & 3.4 & 2.8 \\
Undisturbed & Palancares & 4.6 & 4.5 \\
Natural & Sumidero & 6.0 & 10.2 \\
\hline
\end{tabular}

Table 3. Parameter values of Equation (1) (binomial part of the zero-inflated model), estimates, standard errors, and $p$-values to estimate the number of recruits (treatment effect) in Spanish black pine forests subjected to treatments in Cuenca Mountains (Spain).

\begin{tabular}{ccccc}
\hline Treatment & Parameter & $\begin{array}{c}\text { Estimate } \\
\text { (Seedlings } \mathbf{~ m}^{\mathbf{2}} \text { ) }\end{array}$ & Std. Error & $\boldsymbol{p}$-Value \\
\hline Compaction & $\beta_{0, T}$ & 0.3239 & 0.2395 & 0.1760 \\
(C, intercept) & $\beta_{1, T}$ & -3.8625 & 0.8508 & $<0.0001$ \\
Undisturbed (U) & $\beta_{2, T}$ & -2.4634 & 0.4848 & $<0.0001$ \\
Scarification (S) & $\beta_{3, T}$ & -3.4377 & 0.7930 & $<0.0001$ \\
Natural (N) & & & & \\
\hline
\end{tabular}

Table 4. Parameter values of Equation (2) (count part of the zero-inflated model), estimates, standard errors and $p$-values to estimate the number of recruits (treatment effect) in Spanish black pine forests subjected to treatments in Cuenca Mountains (Spain).

\begin{tabular}{ccccc}
\hline Treatment & Parameter & $\begin{array}{c}\text { Estimate } \\
{\text { (Seedlings } \mathbf{~}^{2} \text { ) }}\end{array}$ & Std. Error & $\boldsymbol{p}$-Value \\
\hline Compaction & $\gamma_{0, T}$ & 0.8342 & 0.1243 & $<0.0001$ \\
(C, intercept) & $\gamma_{1, T}$ & 0.5751 & 0.1358 & $<0.0001$ \\
Undisturbed (U) & $\gamma_{2, T}$ & 0.3067 & 0.1417 & 0.0304 \\
Scarification (S) & $\gamma_{3, T}$ & 0.9936 & 0.1386 & $<0.0001$ \\
Natural (N) & & & & \\
\hline
\end{tabular}


With respect to the effect of the three forests on the recruitment occurrence, the Sumidero forest presents the highest probability, followed by Palancares and Majadas. Very similar results are observed when it comes to the abundance of recruits. Given that recruitment occurs, Sumidero is expected to see larger numbers of individuals, followed by Palancares and Majadas. The parameter estimates for this model can be found in Tables 5 and 6 . The model predictions and confidence intervals by treatments and sites can be seen in Figures 2 and 3.

Table 5. Parameter values of Equation (3) (binomial part of the zero-inflated model), estimates, standard errors and $p$-values to estimate the number of recruits (forest effect) in three Spanish black pine forests of Cuenca Mountains (Spain).

\begin{tabular}{ccccc}
\hline Forest & Parameter & $\begin{array}{c}\text { Estimate } \\
\text { (Seedlings } \mathbf{~ m}^{\mathbf{2}} \text { ) }\end{array}$ & Std. Error & $\boldsymbol{p}$-Value \\
\hline Majadas-harvested (M, intercept) & $\beta_{0, F}$ & -0.6536 & 0.1988 & 0.0010 \\
Palancares-harvested (P) & $\beta_{1, F}$ & -1.1322 & 0.3323 & 0.0007 \\
Sumidero-unmanaged (S) & $\beta_{2, F}$ & -2.4634 & 0.7817 & 0.0016 \\
\hline
\end{tabular}

Table 6. Parameter values of Equation (4) (count part of the zero-inflated model), estimates, standard errors and $p$-values to estimate the number of recruits (forest effect) in Spanish black pine forests of Cuenca Mountains (Spain).

\begin{tabular}{ccccc}
\hline Forest & Parameter & $\begin{array}{c}\text { Estimate } \\
\text { (Seedlings } \mathbf{~ m}^{\mathbf{2}} \text { ) }\end{array}$ & Std. Error & $\boldsymbol{p}$-Value \\
\hline Majadas-harvested (M, intercept) & $\gamma_{0, F}$ & 1.07037 & 0.06808 & $<0.0010$ \\
Palancares-harvested (P) & $\gamma_{1, F}$ & 0.26157 & 0.08448 & 0.0020 \\
Sumidero-unmanaged (S) & $\gamma_{2, F}$ & 0.75743 & 0.09172 & $<0.0001$ \\
\hline
\end{tabular}

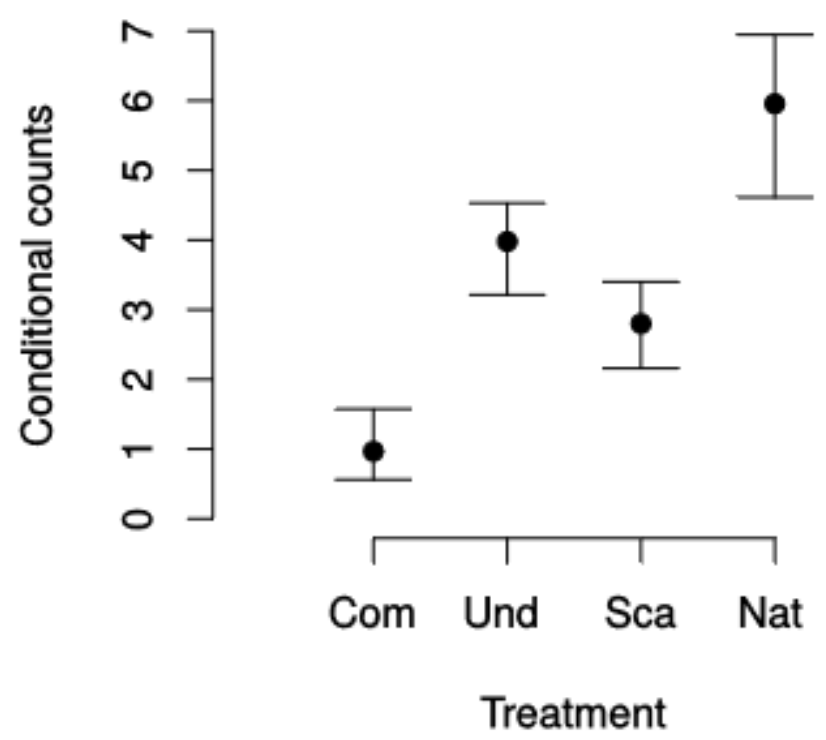

Figure 2. Zero-inflated model predictions and confidence intervals of number of recruits after treatments per $\mathrm{m}^{2}(\mathrm{Com}=$ Compaction; Und = Undisturbed; Sca = Scarification; Nat $=$ Natural (Sumidero) $)$ in three Spanish black pine forests (Cuenca Mountains, Spain). 


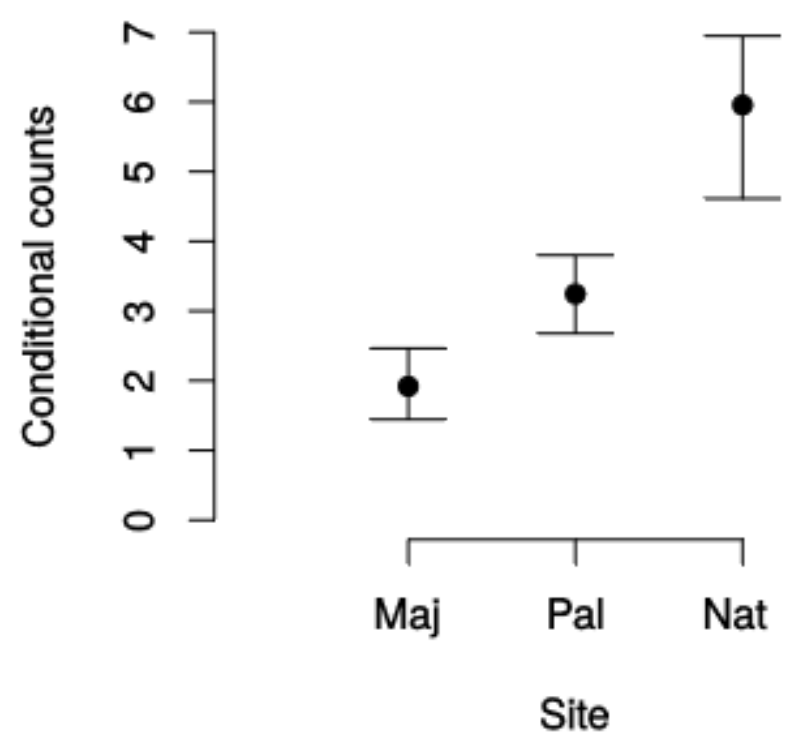

Figure 3. Zero-inflated model predictions and confidence intervals of number of recruits per $\mathrm{m}^{2}$ in three Spanish black pine forests (Maj = Majadas; $\mathrm{Pal}=$ Palancares; Nat = Natural (Sumidero)) subjected to treatments or unmanaged (Cuenca Mountains, Spain).

\section{Discussion}

Studying the incidence that harvest operations have on initial seedling recruitment is important, but it is also a complex task for which very little background is available. Our study provides evidence that tree harvest operations through skidding trails after tree harvesting or soil areas scarified by felled trees can significantly reduce Spanish black pine seedling emergence in comparison to areas undisturbed by harvest operations and unmanaged stands. In addition, initial recruitment was significantly lower at the upper elevation limit of Spanish black pine in comparison to the core of the Spanish black pine range in the Cuenca Mountains and the unmanaged stand (Sumidero).

Our results indicated that seed fall and the seedling density were similar to previous values found at the same experimental areas $[22,25,33]$. Furthermore, since parent rock material, topography, and soil characteristics were similar among study sites (i.e., the Palancares and Majadas sites), differences with respect to seedling emergence can be associated with climate and the influence of harvest operations on soil properties when comparing harvested and non-harvested Spanish black pine stands. In addition, forest structure characteristics may also play a role when comparing harvested or non-harvested stands with the unmanaged site.

Because seedling recruitment is ultimately limited by the quantity of viable seed fall, an evaluation of seedling patterns is necessary to understand the dynamics of recruitment [34]. Such understanding is critical for Spanish black pine, which is a species requiring particular conservation measures due to natural regeneration problems in relict or typical stands. Pine seeds are dispersed across a wide variety of sites covering a range of abiotic and biotic conditions [33]. Given that a similar forest structure of Spanish black pine always dominates all managed stands at each experimental site, we can assume that seed fall was similar at compaction, undisturbed, and scarification treatments at each experimental forest. Moreover, it is worth noting that the Palancares site presented higher seed fall in comparison to the Majadas site, which in turn leads with higher seedling density at Palancares in comparison to the Majadas forest [15]. Reductions in seed quantity with elevation have been reported in the Spanish black pine population in the Cuenca Mountains [35]. This could be related to differences in soil and climatic conditions, which can be important in modifying seed production trends at high altitudes. Moreover, it has been noticed that pines under more stressed conditions tend to produce solely male seeds or even to stop reproducing [34]. Obviously, seed fall was higher in the unmanaged stand, as higher tree density was recorded at this site in comparison to harvested plots. Moreover, the different forest 
structure found at the unmanaged stand may also generate higher seedling recruitment as Spanish black pine seed emergence is generally related to canopy cover [15].

Under adequate moisture and temperatures, Spanish black pine seeds will emerge readily following release from the cone [36,37]. Emergence under field conditions can also be temporally variable, as different microhabitats provide appropriate conditions for emergence at different times [38]. In Mediterranean areas, seedling emergence is unlikely to occur during the dry summer and is instead often restricted to short periods in the wetter spring or autumn [39]. After seed fall, seedling emergence represents a risky transition from the seed stage (the most tolerant to environmental conditions) to the seedling stage (when the plant is weakest and most vulnerable). One interesting question for this research is whether those changes in seedling emergence are related to differences in harvesting activities and influenced by the associated forest structure or climate conditions. Our results demonstrated that seedling emergence was significantly higher in the unmanaged forest, followed by scarified, undisturbed soils, and compacted soils. Logically, the unmanaged forest presented a higher seedling emergence because a higher seed fall was found on site. With respect to harvested sites (which received the same seed fall quantity), plots scarified by felled trees and soil undisturbed by harvesting presented higher seedling emergence in comparison to plots affected by skidding. Thus, soil compaction generated by the machinery used in harvest operations may decrease seedling emergence. Thirty years after skid trail construction and logging operations, skid trails showed regeneration of only seven species of trees (Acer velutinum Boiss., Acer cappadocicum Gled., Alnus subcordata C. A. Mey., Carpinus betulus L., Fagus orientalis Lipsky., Mespilus germanica L., and Vaccinium microphylla Willd.) at the seedling and sapling stages, whereas the areas undisturbed showed a much higher density and number of tree species [19].

Site preparation has proven to have several positive effects on the establishment of conifer seedlings, such as increased soil temperature [40,41] and soil water availability [42]. In addition, forest managers and researchers are now paying increased attention to site preparation as a means of improving water supply in the root zone of soil [15]. This may be accomplished by removing the competing vegetation, increasing soil water storage, or encouraging more extensive seedling root development [43]. Several site preparation methods have been developed, but the methods most used in Serranía de Cuenca are scalping and brushing [15]. The effectiveness of site preparation will depend on microclimatic conditions, soil characteristics, and the nature of the competing vegetation [41]. There are different site preparation methods. However, it is unclear which method is preferable during the natural regeneration of Spanish black pine. In addition, pine seedlings present a fast root growth and a remarkable soil penetration capacity [25], which enable them to withstand competition from the neighboring ground vegetation by rapidly reaching deeper soil horizons. However, in stands with a well-developed canopy cover, competition for light can limit growth of the seedlings and delay the progressive advance of the recruitment towards more advanced stages [44]. Among the sites in this study, unmanaged areas accounted for the best seedling emergence. Harvest operations were conducted prior to seed fall; thus, lower seedling emergence rates cannot be associated with direct damage to emerged seeds during harvesting or logging. It is most likely that the higher seedling emergence rates detected at the Palancares experimental forest in comparison to the Majadas forest may be related to the higher seed fall and differences in climatic conditions. As mentioned above, higher seed fall in unmanaged stands leads to higher seedling emergence. Therefore, for the unmanaged site, Spanish black pine presented a high seed germination in a higher stand density, allowing seedlings to better obtain the protection of surrounding trees.

The negative effects of drought can be corrected by overstory density to obtain higher seed germination rates [45]. It is usually held that forest stand structures alter light, soil temperature, and moisture conditions and drive natural regeneration processes in different ways [46,47]. For instance, forest canopies cause deterministic processes that consistently redistribute precipitation and soil moisture, highly altering initial recruitment patterns $[48,49]$. Comparing harvested plots at different locations in relict areas, Spanish black pine became more light demanding, and mid-stand openness 
values showed higher seed germination rates. These results confirm the relatively greater shade tolerance of the Spanish black pine compared to other Iberian pines such as Pinus halepensis M. or Pinus pinaster Ait. [48]. Similarly, the higher seed fall found in Palancares in comparison to Majadas also resulted in higher seedling emergence rates in the typical Spanish black pine distribution area in comparison to a more relict habitat. In [35], the authors associated the highest monthly mean soil and air temperature registered in Palancares with the highest number of seeds germinated. There are few studies that relate observations on seed germination of Spanish black pine to soil or air temperature, but some authors have argued that the Spanish black pine seed cover only generates a moderate protection to heat shocks or frost, so high or low temperatures found at relict distribution areas may become lethal, delaying or preventing seed germination [50,51]. This study provided evidence of critical factors involved in harvest operations and earlier stages of regeneration of Spanish black pine in a Mediterranean environment. Overall, decreasing seedling emergence counts going from non-disturbed areas to scarified areas to skid trail areas may not be a problem if harvest operations are properly planned, since the respective proportions of the forest in each of these disturbance classes is usually very high. Other processes and interactions that occur later in the life cycle, such as seedling survival, need to be studied. Knowledge of the survival responses will contribute to the effort to conserve endangered Spanish black pine forest areas in typical and relict locations.

\section{Conclusions}

In two Spanish black pine Mediterranean forests subjected to tree harvesting and soil compaction, scarification, or no further disturbance, differences in seed fall quantities were found among sites (Majadas vs. Palancares) and harvested vs. non-harvested sites. Results showed that Palancares and, logically, non-harvested sites presented higher quantities of seed fall, which was influenced by climatic conditions and forest stand structure. Moreover, tree harvest operations through skidding trails after tree harvesting generated lower seedling emergence rates, whereas soil areas scarified by felled trees or areas unaffected by harvesting generated higher seedling emergence rates. It is worth noting that unmanaged stands also presented higher seedling emergence rates than managed stands (either soil areas scarified by felled trees or unaffected areas), which could be explained by the higher seed fall detected in unmanaged areas. Overall, the differences between surveyed plots suggest the important effects of tree harvesting on seedling emergence. Long-term studies should be planned to corroborate our results.

Author Contributions: Conceptualization, M.E.L.-B.; methodology, M.E.L.-B. and R.M.; formal analysis, R.M. and M.E.L.-B.; data curation, M.E.L.-B., D.A.Z., M.H., I.M.; writing-original draft preparation, M.E.L.-B., R.M., D.A.Z., M.H., I.M.; writing-review and editing, M.E.L.-B., D.A.Z., M.H., I.M.; supervision, M.E.L.-B., D.A.Z., M.H., I.M., R.M. All authors have read and agreed to the published version of the manuscript.

Funding: This research received no external funding.

Acknowledgments: Spanish Ministry of Economy, Industry and Competitiveness Research Projects, BIORESOC (CGL2017-88734-R), and FEDER-Junta de Andalucía Research Projects RESTAGRO (UAL18-RNM-A021-B) and P18-RT-4112 provided financial support aid in this article. Isabel Miralles is grateful for funding received from the Ramón y Cajal Research Grant (RYC-2016-21191) from the Spanish Ministry of Economy, Industry and Competitiveness (MINECO).

Conflicts of Interest: The authors declare no conflict of interest.

\section{References}

1. Oliver, C.D.; Larson, B.C.; Oliver, C.D. Forest Stand Dynamics; John Wiley \& Sons: New York, NY, USA, 1996; p. 520.

2. Ice, G.G.; Neary, D.G.; Adams, P.W. Effects of wildfire on soils and watershed processes. J. For. 2004, 102, $16-20$.

3. Leverkus, A.B.; Lindenmayer, D.B.; Thorn, S.; Gustafsson, L. Salvage Logging in the World's Forests: Interactions between Natural Disturbance and Logging Need Recognition. Glob. Ecol. Biogeogr. 2018, 27, 1140-1154. [CrossRef] 
4. Lucas-Borja, M.E.; Ortega, R.; Miralles, I.; Plaza-Álvarez, P.A.; González-Romero, J.; Peña-Molina, E.; Moya, D.; Zema, D.A.; Wagenbrenner, J.W.; Heras, J.D.L. Effects of Wildfire and Logging on Soil Functionality in the Short-Term in Pinus Halepensis M. For. Eur. J. For. Res. 2020, 6, 2414. [CrossRef]

5. Donato, D.C.; Fontaine, J.B.; Campbell, J.L.; Robinson, W.D.; Kauffman, J.B.; Law, B.E. Post-Wildfire Logging Hinders Regeneration and Increases. Fire Risk Sci. 2006, 311, 352. [CrossRef] [PubMed]

6. Boucher, Y.; Grondin, P.; Auger, I. Land Use History (1840-2005) and Physiography as Determinants of Southern Boreal Forests. Landsc. Ecol. 2013, 29, 437-450. [CrossRef]

7. Knapp, E.E.; Ritchie, M.W. Response of Understory Vegetation to Salvage Logging Following a High-Severity Wildfire. Ecosphere 2016, 7, e01550. [CrossRef]

8. Wagenbrenner, J.W.; Macdonald, L.H.; Coats, R.N.; Robichaud, P.R.; Brown, R.E. Effects of Post-Fire Salvage Logging and a Skid Trail Treatment on Ground Cover, Soils, and Sediment Production in the Interior Western United States. Forest Ecol. Manag. 2015, 335, 176-193. [CrossRef]

9. Prats, S.A.; Malvar, M.C.; Coelho, C.O.A.; Wagenbrenner, J.W. Hydrologic and erosion responses to compaction and added surface cover in post-fire logged areas: Isolating splash, interrill and rill erosion. J. Hydrol. 2019, 575, 408-419. [CrossRef]

10. Kozlowski, T. Physiological Ecology of Natural Regeneration of Harvested and Disturbed Forest Stands: Implications for Forest Management. For. Ecol. Manag. 2002, 158, 195-221. [CrossRef]

11. Calama, R.; Manso, R.; Lucas Borja, M.E.; Espelta, J.M.; Piqué, M.; Bravo Oviedo, F.; Peso Taranco, C.E.D.; Pardos, M. Natural regeneration in Iberian pines: A review of dynamic processes and proposals for management. For. Syst. 2017, 26, 1-20. [CrossRef]

12. Modrý, M.; Hubený, D.; Rejšek, K. Differential Response of Naturally Regenerated European Shade Tolerant Tree Species to Soil Type and Light Availability. For. Ecol. Manag. 2004, 188, 185-195. [CrossRef]

13. Neeman, G.; Goubitz, S.; Nathan, R. Reproductive Traits of Pinus halepensis in the Light of Fire-a Critical Review. Plant Ecol. 2004, 171, 69-79. [CrossRef]

14. Vergarechea, M.; del Río, M.; Gordo, J.; Martín, R.; Cubero, D.; Calama, R. Spatio-temporal variation of natural regeneration in Pinus pinea and Pinus pinaster Mediterranean forests in Spain. Eur. J. For. Res. 2019, 138, 313-326. [CrossRef]

15. Lucas-Borja, M.; Fonseca, T.; Linares, J.; Morote, F.G.; Serrano, F.L. Does the Recruitment Pattern of Spanish Black Pine (Pinus nigra Arn. ssp. salzmannii) Change the Regeneration Niche over the Early Life Cycle of Individuals? For. Ecol. Manag. 2012, 284, 93-99. [CrossRef]

16. Prévosto, B.; Amandier, L.; Quesney, T.; Boisgelin, G.D.; Ripert, C. Regenerating Mature Aleppo Pine Stands in Fire-Free Conditions: Site Preparation Treatments Matter. For. Ecol. Manag. 2012, 282, 70-77. [CrossRef]

17. Herrera, C.M. Historical Effects and Sorting Processes as Explanations for Contemporary Ecological Patterns: Character Syndromes in Mediterranean Woody Plants. Am. Nat. 1992, 140, 421-446. [CrossRef]

18. Prévosto, B.; Gavinet, J.; Ripert, C.; Fernandez, C. Identification of Windows of Emergence and Seedling Establishment in a Pine Mediterranean Forest under Controlled Disturbances. Basic Appl. Ecol. 2015, 16, 36-45. [CrossRef]

19. Tavankar, F. Plant species recovery and natural tree regeneration on skid trails in the Hyrcanian forests of Iran. J. Biodivers. Environ. Sci. 2013, 3, 10-16.

20. Gomez, A.; Powers, R.F.; Singer, M.J.; Horwath, W.R. Soil Compaction Effects on Growth of Young Ponderosa Pine Following Litter Removal in Californias Sierra Nevada. Soil Sci. Soc. Am. J. 2002, 66, 1334-1343. [CrossRef]

21. Bassett, I.E.; Simcock, R.C.; Mitchell, N.D. Consequences of Soil Compaction for Seedling Establishment: Implications for Natural Regeneration and Restoration. Austral Ecol. 2005, 30, 827-833. [CrossRef]

22. Lucas-Borja, M.E.; Fonseca, T.F.; Lousada, J.L.; Silva-Santos, P.; Garcia, E.M.; Abellán, M.A. Natural Regeneration of Spanish Black Pine [Pinus nigra Arn. ssp. salzmannii (Dunal) Franco] at Contrasting Altitudes in a Mediterranean Mountain Area. Ecol. Res. 2012, 27, 913-921. [CrossRef]

23. Aleksandrowicz-Trzcińska, M.; Drozdowski, S.; Studnicki, M.; Żybura, H. Effects of Site Preparation Methods on the Establishment and Natural-Regeneration Traits of Scots Pines (Pinus sylvestris L.) in Northeastern Poland. Forests 2018, 9, 717. [CrossRef]

24. Lucas-Borja, M.E.; González-Romero, J.; Plaza-Álvarez, P.; Sagra, J.; Gómez, M.; Moya, D.; Cerdà, A.; Heras, J.D.L. The Impact of Straw Mulching and Salvage Logging on Post-Fire Runoff and Soil Erosion Generation under Mediterranean Climate Conditions. Sci. Total Environ. 2019, 654, 441-451. [CrossRef] [PubMed] 
25. Del Cerro Barja, A.; Lucas-Borja, M.E.; García, E.M.; Serrano, F.R.L.; Abellán, M.A.; Morote, F.A.G.; López, R.N. Influence of Stand Density and Soil Treatment on the Spanish Black Pine (Pinus nigra Arn. ssp. salzmannii) Regeneration in Spain. For. Syst. 2009, 18, 167.

26. Fleming, R.L.; Black, T.A.; Adams, R.S.; Stathers, R.J. Silvicultural treatments, microclimatic conditions and seedling response in Southern interior clearcuts. Can. J. Forest Res. 1998, 78, 115-126. [CrossRef]

27. Harper, J.L. Population Biology of Plants; Blackburn Press: Caldwell, NJ, USA; London, UK, 2010; p. 892.

28. Soil Survey Staff, Soil Taxonomy. A Basic System of Soil Classification for Making and Interpreting Soil Surveys, 2nd ed.; USDA Natural Resources Conservation Service: Washington, DC, USA, 1999; p. 869.

29. Lucas-Borja, M.E.; Candel-Pérez, D.; Morote, F.A.G.; Onkelinx, T.; Tíscar, P.A.; Balandier, P. Pinus nigra Arn. ssp. salzmannii Seedling Recruitment Is Affected by Stand Basal Area, Shrub Cover and Climate Interactions. Ann. For. Sci. 2016, 73, 649-656. [CrossRef]

30. Fortin, M.; DeBlois, J. Modeling Tree Recruitment with Zero-Inflated Models: The Example of Hardwood Stands in Southern Québec, Canada. For. Sci. 2007, 53, 529-539.

31. Manso, R.; Ligot, G.; Fortin, M. A recruitment model for beech-oak pure and mixed stands in Belgium, Forestry. Int. J. For. Res. 2020, 93, 124-132.

32. Zeileis, A.; Kleiber, C.; Jackman, S. Regression Models for Count Data in R. J. Stat. Softw. 2008, $27,1-25$. [CrossRef]

33. Schupp, E.W. Annual Variation in Seedfall, Postdispersal Predation, and Recruitment of a Neotropical Tree. Ecology 1990, 71, 504-515. [CrossRef]

34. Lucas-Borja, M.E.; Vacchiano, G. Interactions between Climate, Growth and Seed Production in Spanish Black Pine (Pinus nigra Arn. ssp. salzmannii) Forests in Cuenca Mountains (Spain). New For. 2018, 49, 399-414. [CrossRef]

35. Lucas-Borja, M.E.; Fonseca, T.; Parresol, B.R.; Silva-Santos, P.; García-Morote, F.A.; Tíscar-Oliver, P.A. Modelling Spanish Black Pine Seedling Emergence: Establishing Management Strategies for Endangered Forest Areas. For. Ecol. Manag. 2011, 262, 195-202. [CrossRef]

36. Shmida, A.; Ne'eman, G.; Goubitz, S.; Lev-Yadun, S. Sexual Allocation and Gender Segregation in Pinus halepensis, P. brutia and P. pinea. In Ecology, Biogeography and Management of Pinus halepensis and P. brutia Forest Ecosystems in the Mediterranean Basin; Ne'eman, G., Trabaud, L., Eds.; Backhuys Publishers: Leiden, Holland, 2000; pp. 91-104.

37. Richardson, D.M.; Allsopp, N.; Dantonio, C.M.; Milton, S.J.; Rejmánek, M. Plant Invasions-the Role of Mutualisms. Biol. Rev. 2007, 75, 65-93. [CrossRef]

38. Nilsson, M.C.; Zackrisson, O.; Sterner, O.; Wallstedt, A. Characterisation of the Differential Interference Effects of Two Boreal Dwarf Shrub Species. Oecologia 2000, 123, 122-128. [CrossRef] [PubMed]

39. Quilichini, A.; Debussche, M. Seed Dispersal and Germination Patternsin a Rare Mediterranean Island Endemic (Anchusa crispa Viv., Boraginaceae). Acta Oecol. 2000, 21, 303-313. [CrossRef]

40. Ritari, A.; Ladhe, E. Effect of site preparation on physical properties of the soil in a thick-humus spruce stand. Comm. Inst. For. Fenn. 1978, 92, 1-36.

41. Örlander, G.; Rosvall-Åhnebrink, G. Evaluating Seedling Quality by Determining Their Water Status. Scand. J. For Res. 1987, 2, 167-177.

42. Bassman, J.H. Influence of two site preparation treatments on ecophysiology of planted Picea engelmanniix glauca seedlings. Can. J. For. Res. 1989, 19, 1359-1370. [CrossRef]

43. Flint, L.; Childs, S. Effect of Shading, Mulching and Vegetation Control on Douglas-Fir Seedling Growth and Soil Water Supply. For. Ecol. Manag. 1987, 18, 189-203. [CrossRef]

44. Martín-Alcón, S.; Coll, L. Unraveling the Relative Importance of Factors Driving Post-Fire Regeneration Trajectories in Non-Serotinous Pinus nigra Forests. For. Ecol. Manag. 2016, 361, 13-22. [CrossRef]

45. Agestam, E.; Ekö, P.M.; Nilsson, U.; Welander, N. The Effects of Shelterwood Density and Site Preparation on Natural Regeneration of Fagus Sylvatica in Southern Sweden. For. Ecol. Manag. 2003, 176, 61-73. [CrossRef]

46. Pötzelsberger, E.; Hasenauer, H. Soil Change after 50years of Converting Norway Spruce Dominated Age Class Forests into Single Tree Selection Forests. For. Ecol. Manag. 2015, 338, 176-182. [CrossRef]

47. Heydari, M.; Prévosto, B.; Abdi, T.; Mirzaei, J.; Mirab-Balou, M.; Rostami, N.; Khosravi, M.; Pothier, D. Establishment of Oak Seedlings in Historically Disturbed Sites: Regeneration Success as a Function of Stand Structure and Soil Characteristics. Ecol. Eng. 2017, 107, 172-182. [CrossRef] 
48. Heydari, M.; Prévosto, B.; Naji, H.R.; Mehrabi, A.A.; Pothier, D. Influence of Soil Properties and Burial Depth on Persian Oak (Quercus brantii Lindl.) Establishment in Different Microhabitats Resulting from Traditional Forest Practices. Eur. J. For. Res. 2017, 136, 287-305. [CrossRef]

49. Keim, R.F.; Skaugset, A.E.; Weiler, M. Storage of water on vegetation under simulated rainfall of varying intensity. Adv. Water Resour. 2006, 29, 974-986. [CrossRef]

50. Fyllas, N.M.; Dimitrakopoulos, P.G.; Troumbis, A.Y. Regeneration Dynamics of a Mixed Mediterranean Pine Forest in the Absence of Fire. For. Ecol. Manag. 2008, 256, 1552-1559. [CrossRef]

51. Escudero, A.; Carnes, L.F.; Pérez-García, F. Seed Germination of Gypsophytes and Gypsovags in Semi-Arid Central Spain. J. Arid Environ. 1997, 36, 487-497. [CrossRef]

(C) 2020 by the authors. Licensee MDPI, Basel, Switzerland. This article is an open access article distributed under the terms and conditions of the Creative Commons Attribution (CC BY) license (http://creativecommons.org/licenses/by/4.0/). 